\title{
Drilling-induced and logging-related features illustrated from IODP-ICDP Expedition 364 downhole logs and borehole imaging tools
}

\author{
Johanna Lofi ${ }^{1}$, David Smith ${ }^{2}$, Chris Delahunty ${ }^{3}$, Erwan Le Ber ${ }^{4}$, Laurent Brun ${ }^{1}$, Gilles Henry ${ }^{1}$, \\ Jehanne Paris ${ }^{1}$, Sonia Tikoo ${ }^{5}$, William Zylberman ${ }^{6}$, Philippe A. Pezard ${ }^{1}$, Bernard Célérier ${ }^{1}$, \\ Douglas R. Schmitt ${ }^{7,8}$, Chris Nixon ${ }^{7}$, and Expedition 364 Science Party $^{*}$ \\ ${ }^{1}$ Géosciences Montpellier, University of Montpellier, CNRS, University of Antilles, Montpellier, France \\ ${ }^{2}$ British Geological Survey, UK \\ ${ }^{3}$ DOSECC Exploration Services, Salt Lake City, Utah, USA \\ ${ }^{4}$ Department of Geology, University of Leicester, UK \\ ${ }^{5}$ Department of Earth and Planetary Sciences, Rutgers University, New Jersey, USA \\ ${ }^{6}$ Centre Européen de Recherche et d'Enseignement des Géosciences de l'Environnement, \\ Aix-en-Provence, France \\ ${ }^{7}$ Department of Physics, University of Alberta, Canada \\ ${ }^{8}$ Department of Earth, Atmospheric, and Planetary Sciences, Purdue University, Indiana, USA \\ ${ }^{*}$ A full list of authors and their affiliations appears at the end of the paper.
}

Correspondence: Johanna Lofi (johanna.lofi@gm.univ-montp2.fr)

Received: 7 December 2017 - Revised: 14 September 2018 - Accepted: 24 September 2018 - Published: 22 October 2018

\begin{abstract}
Expedition 364 was a joint IODP and ICDP mission-specific platform (MSP) expedition to explore the Chicxulub impact crater buried below the surface of the Yucatán continental shelf seafloor. In April and May 2016, this expedition drilled a single borehole at Site M0077 into the crater's peak ring. Excellent quality cores were recovered from $\sim 505$ to $\sim 1335 \mathrm{~m}$ below seafloor (m b.s.f.), and high-resolution open hole logs were acquired between the surface and total drill depth. Downhole logs are used to image the borehole wall, measure the physical properties of rocks that surround the borehole, and assess borehole quality during drilling and coring operations. When making geological interpretations of downhole logs, it is essential to be able to distinguish between features that are geological and those that are operation-related. During Expedition 364 some drilling-induced and logging-related features were observed and include the following: effects caused by the presence of casing and metal debris in the hole, logging-tool eccentering, drilling-induced corkscrew shape of the hole, possible re-magnetization of low-coercivity grains within sedimentary rocks, markings on the borehole wall, and drilling-induced changes in the borehole diameter and trajectory.
\end{abstract}

\section{Introduction}

Expedition 364 was a joint International Ocean Discovery Program (IODP) and International Continental Scientific Drilling Program (ICDP) Mission Specific Platform (MSP) expedition (Morgan et al., 2017). It drilled and cored a single borehole (Hole M0077A) at a shallow water depth in the Chicxulub impact crater buried below the surface of the Yucatán continental shelf (Mexico). This crater is the best preserved of the three largest impact structures on the earth (Grieve and Therriault, 2000), has an intact, unequivocal topographic peak ring, is associated with a global ejecta layer, and has been directly linked to the K-Pg mass extinction (e.g., Schulte et al., 2010; Kring, 2007).

The post-impact sedimentary cover sequence $(0-$ $617.33 \mathrm{~m}$ b.s.f.) and the peak ring of the Chicxulub impact crater (617.33-1334.69 m b.s.f.) were drilled during Expedition 364 (Fig. 1c). Details on both scientific objectives and 


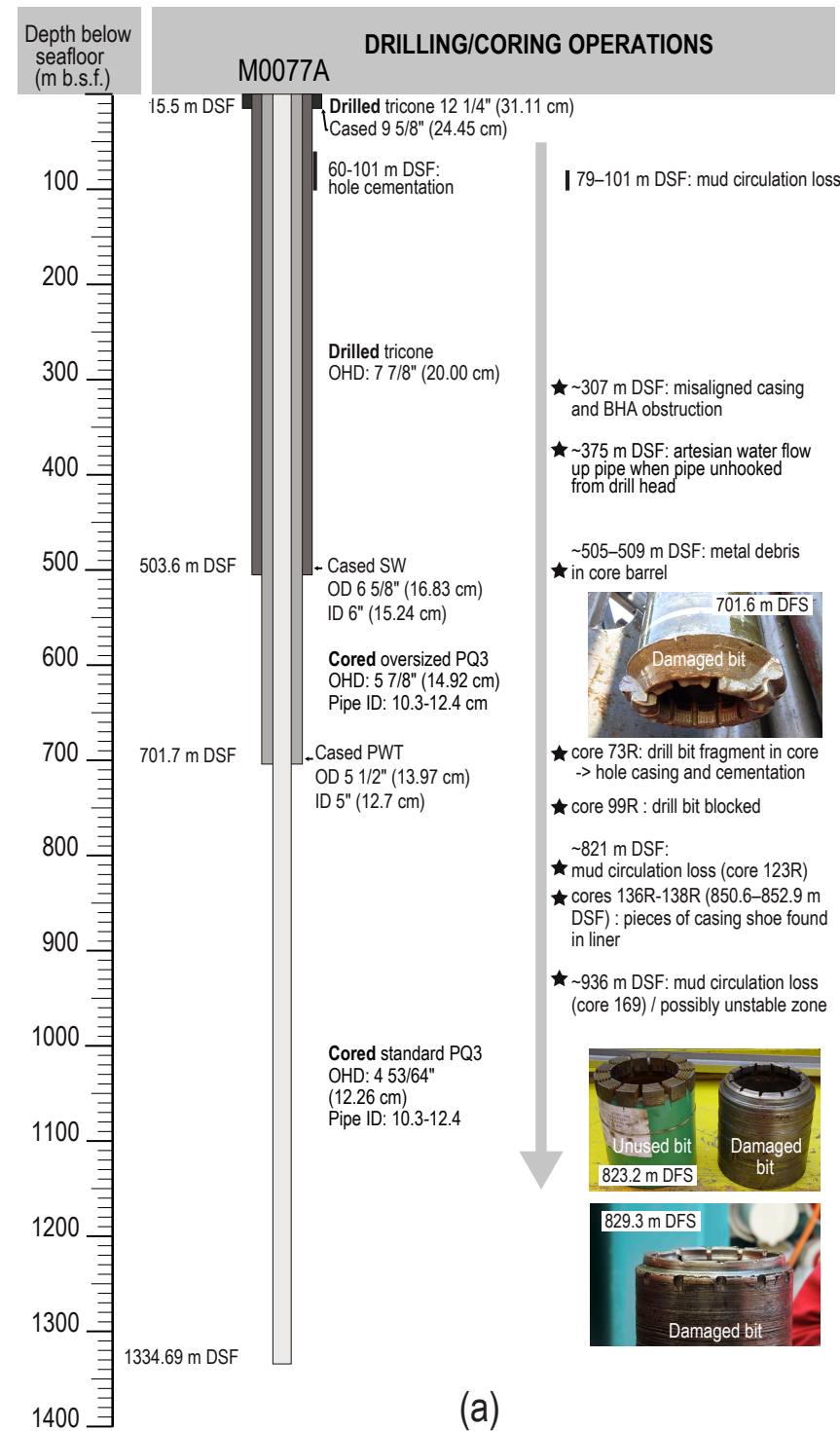

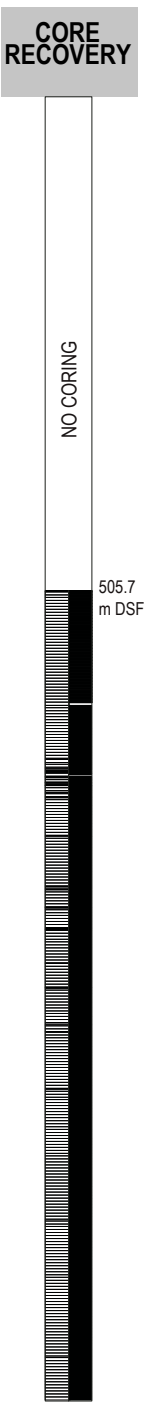

(b)

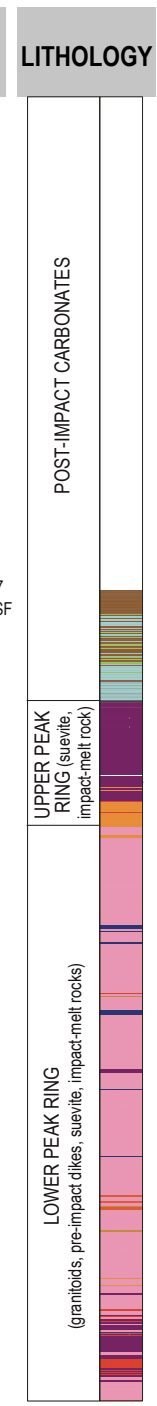

(c)

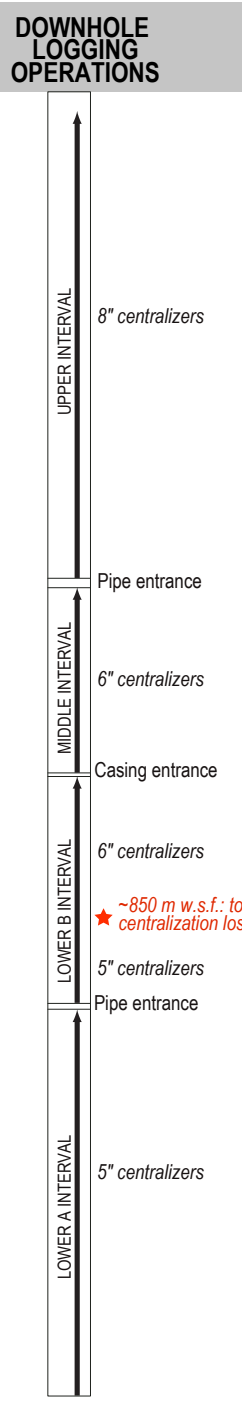

(d)

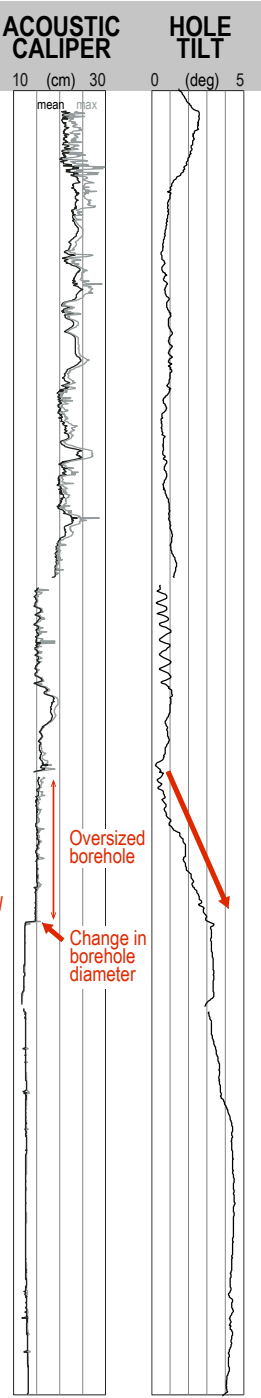

(e)

(f)

Figure 1. Summary of drilling, coring, and logging operations at Site M0077. The downhole logging data were acquired with slimline tools in three different phases (upper, middle, and lower intervals). Note the change in borehole diameter at $\sim 850 \mathrm{~m}$ w.s.f. (wireline seafloor) preceded by an increase in the borehole tilt (see discussion in Sect. 4.3). Pictures illustrate damaged drill bits. ID is the inner diameter, OD the outer diameter, and OHD the open hole diameter; m b.s.f. is meters below seafloor and DSF is the driller's depth below seafloor.

operations can be found in the IODP proceeding volume (Morgan et al., 2017). In total, 303 cores were recovered from 505.7 to 1334.69 mb.s.f. (Fig. 1b). Open hole downhole logs were acquired with slimline tools over almost the entire depth (Fig. 1d). Due to favorable borehole conditions, the recovery and overall quality of the downhole logging data are good to excellent, with the exception of the upper $\sim 400 \mathrm{~m}$ b.s.f. within the rotary drilled younger carbonates that exhibit karst features.

In general, downhole wireline logging tools are used to measure a suite of physical properties within the rocks surrounding the borehole as well as to image the borehole wall.
These logs provide critical geological information about the rock formations close to the borehole, including their lithology, fluid content, porosity, and structural data such as the presence of faults and fractures. Where core recovery is incomplete, log data provide an invaluable way to characterize the geological formation. Where core recovery is good, $\log$ and core data are complementary and can be interpreted jointly. In addition, downhole logs measure formation properties on a scale that is intermediate between the one obtained from measurements on core samples at the laboratory and the one obtained from surface geophysical surveys. Logging is thus useful for the integration of physical prop- 
erties at various scales. Downhole logs can also allow the assessment of borehole quality (e.g., hole shape and trajectory) and can provide assistance with decision support during drilling and coring operations. Differentiating between in situ natural geological features, generally also visible on cores, and drilling-induced or logging-related features is part of the data quality control process and is critical for the interpretation of well-log data. Logging-related and drillinginduced features have been described in several studies (e.g., Lofts and Bourke, 1999; Cheung, 1999); here, we provide examples from Site M0077. We focus mainly on acoustic borehole images that provide invaluable source of information for sub-surface geology characterization. We will also show how downhole logs have been used to improve the post-operation understanding of the drilling and coring operation history.

\section{Expedition 364 offshore operations}

As for all MSP expeditions, the downhole logging program was coordinated by the European Petrophysics Consortium (EPC), which is part of the European Consortium for Ocean Drilling (ECORD) Science Operator (ESO). MSPs employ various coring technologies and pipe sizes (here PDC Tricone, oversize PQ3, PQ3; Fig. 1a) and drill in a variety of water depths (here $<20 \mathrm{~m}$ water depth), each of which provides technical constraints on the nature of logging operations and the set of downhole geophysical tools that can be used on a case-by-case basis. Taking into account the technical constraints, the logging program is designed to help meet the expedition-specific scientific objectives.

\subsection{Overview of downhole logging operations}

For Expedition 364, downhole logging operations at Site M0077 were funded by the ICDP. Slimline wireline logging services were contracted by EPC from the University of Montpellier-CNRS (France). Logged data included total gamma radiation, sonic velocity, acoustic and optical images of the borehole wall, electrical formation resistivity, induction formation conductivity, magnetic susceptibility, magnetic field azimuth and intensity, and caliper and borehole fluid parameters (Table 1). Details on logging procedure and logging-tool measurement principles can be found in Morgan et al. (2017). Additional technical schemes on individual logging tools and information can be found on the tool manufacturers' websites (http://geovista.co.uk/, last access: 12 October 2018 and https://www.alt.lu/, last access: 12 October 2018).

Logs were recorded either with stand-alone logging tools or for the first time in MSPs, with stackable ultra-slimline tools (tool diameter without centralizers: 3.8 to $5.2 \mathrm{~cm}$ ) combined into tool strings. Most of the measurements were acquired in open borehole conditions (no casing). Hole M0077A was drilled using a series of drill strings of reducing diameters down to the base of the hole at $1334.7 \mathrm{~m}$ b.s.f.
(Fig. 1a). The downhole logging runs were performed in stages in order to allow the hole to be cased and ensure the hole remained open and logs could be collected from the entire drilled interval. Data were acquired in three logging phases at intervals $\sim 0-503$ (upper interval), 506-699 (middle interval) and $\sim 700-1334 \mathrm{~m}$ (lower interval) wireline seafloor (m w.s.f.; Fig. 1d). In preparation for logging, the boreholes were either flushed of debris by circulating sea water (upper and lower intervals) or left filled with drill mud (middle interval). In each interval logged, the bottom hole assembly (BHA) was either pulled up, or entirely pulled out. During each logging run, incoming data were recorded and monitored in real time with a data acquisition system. As the $L / B$ Myrtle drill ship was jacked up above the sea surface, there was no ship heave and thus no need to use a wireline heave compensator.

Advanced Logic Technology (ALT)'s WellCAD software package was used for the visualization, processing, and plotting of the downhole data. The processed data are available online in the IODP database (http://mlp.ldeo.columbia. edu/logdb/scientific_ocean_drilling/, last access: 12 October 2018) along with information about how they were collected and processed. Further information can be found in Morgan et al. (2017). During the processing of the downhole logging data, both drilling-induced and logging-related features were noticed. These are described below, and should be kept in mind when making any future geological interpretations of the logging data. In addition, most of the features discussed are not specific to Expedition 364 or to slimline tools and could be observed in logging data acquired during other IODP Expeditions.

\subsection{Borehole-imaging logging tools}

Borehole-imaging logging tools are commonly used by both the IODP and ICDP (e.g., Lovell et al., 1998). They involve measuring either the electrical conductivity of the borehole wall (Formation MicroScanner tool, Pezard and Lovell et al., 1990; Gaillot et al., 2007; Pezard et al., 1992a, b; Ekstrom et al., 1987) or the sonic travel time and amplitude of a reflected ultrasonic pulse (acoustic borehole imager - ABI in this study; Table 1; Zemanek et al., 1969, 1970; Zoback and Anderson, 1982; Anderson and Zoback, 1983; Hayman et al., 1998). A third category allows for the recording of an optical image of the borehole wall (optical borehole imager OBI - in this study; Table 1; e.g., Paillet et al., 1990; Inwood et al., 2008).

During Expedition 364, both optical and acoustic borehole imagers were used. The OBI tool used has the ability to produce high-resolution optical images of the borehole wall down to a millimeter scale (https://www.alt.lu/). This logging tool incorporates a high-resolution, high-sensitivity CCD digital camera located above a conical mirror that captures the image of the borehole wall. The light source is provided by an LED ring assembly located in the optical head. 
Table 1. Summary of wireline slimline probes; Expedition 364. Modified from Morgan et al. (2017).

\begin{tabular}{|c|c|c|c|c|c|c|}
\hline \multirow{2}{*}{$\begin{array}{l}\text { Wireline tool } \\
\text { Stackable }\end{array}$} & \multicolumn{2}{|c|}{$\begin{array}{l}\text { Slimline tools acronyms and full } \\
\text { name }\end{array}$} & \multirow{2}{*}{$\begin{array}{l}\text { Manufacturer } \\
\text { ALT/Mount } \\
\text { Sopris } \\
\text { Instruments }\end{array}$} & \multirow{2}{*}{$\begin{array}{l}\text { Tool string } \\
\text { position }\end{array}$} & \multirow{2}{*}{$\begin{array}{l}\text { Focus on } \\
\text { Formation }\end{array}$} & \multirow{2}{*}{$\begin{array}{l}\text { Measurement } \\
\text { spacing interval } \\
\text { (up logs) }\end{array}$} \\
\hline & QL40-SGR & $\begin{array}{l}\text { Spectral } \\
\text { Gamma Ray } \\
\text { Probe }\end{array}$ & & & & \\
\hline & QL40-FWS & $\begin{array}{l}\text { Full Waveform } \\
\text { Sonic }\end{array}$ & $\begin{array}{l}\text { ALT/Mount } \\
\text { Sopris } \\
\text { Instruments }\end{array}$ & In-line sub & Formation & $5-10 \mathrm{~cm}$ \\
\hline & QL40-Ocean & $\begin{array}{l}\text { Idronaut Ocean } \\
\text { Seven }\end{array}$ & $\begin{array}{l}\text { ALT/Mount } \\
\text { Sopris } \\
\text { Instruments }\end{array}$ & Bottom sub & Borehole fluids & $5 \mathrm{~cm}$ \\
\hline & QL40-CAL & 3 Arm Caliper & $\begin{array}{l}\text { ALT/Mount } \\
\text { Sopris } \\
\text { Instruments }\end{array}$ & In-line sub & Borehole wall & $5 \mathrm{~cm}$ \\
\hline & QL40-FTC & $\begin{array}{l}\text { Fluid Tempera- } \\
\text { ture and } \\
\text { Conductivity }\end{array}$ & $\begin{array}{l}\text { ALT/Mount } \\
\text { Sopris } \\
\text { Instruments }\end{array}$ & Bottom sub & Borehole fluids & $5 \mathrm{~cm}$ \\
\hline & QL40-OBI & $\begin{array}{l}\text { Optical Bore- } \\
\text { hole Imager }\end{array}$ & $\begin{array}{l}\text { ALT/Mount } \\
\text { Sopris } \\
\text { Instruments }\end{array}$ & Bottom sub & Borehole wall & $\begin{array}{l}2 \mathrm{~mm} \\
360 \\
\text { points/revolution }\end{array}$ \\
\hline & QL40-ABI & $\begin{array}{l}\text { Acoustic Bore- } \\
\text { hole Imager }\end{array}$ & $\begin{array}{l}\text { ALT/Mount } \\
\text { Sopris } \\
\text { Instruments }\end{array}$ & Bottom sub & $\begin{array}{l}\text { Borehole wall, } \\
\text { inclinometry }\end{array}$ & $\begin{array}{l}2-4 \mathrm{~mm} \\
144-288 \\
\text { points/revolution }\end{array}$ \\
\hline \multirow[t]{2}{*}{ Stand-alone } & DLL3 & $\begin{array}{l}\text { Dual Focused } \\
\text { Resistivity }\end{array}$ & Geovista & NA & Formation & $5-10 \mathrm{~cm}$ \\
\hline & EM51 & $\begin{array}{l}\text { Magnetic Sus- } \\
\text { ceptibility and } \\
\text { Induction }\end{array}$ & Geovista & NA & Formation & $5-10 \mathrm{~cm}$ \\
\hline
\end{tabular}

Notes: ALT is advanced logic technology. QL stands for quick link.

By using processed camera data in combination with deviation sensor data, the tool can generate an unwrapped image oriented by $360^{\circ}$. Image quality degrades with hole diameters larger than $15 \mathrm{~cm}(6 \mathrm{in}$.) and with the presence of mud in the borehole, as the tool is designed for logs either in air or clear water. The OBI tool cannot be used in the presence of mud cake. During Expedition 364, OBI images during up logs were acquired with various resolutions, ranging from 360 samples by $4 \mathrm{~mm}$ or 360 samples by $2 \mathrm{~mm}$ (Table 1, Morgan et al., 2017).

The ABI downhole tool used during Expedition 364 produces a $1.2 \mathrm{MHz}$ ultrasonic pulse sent toward the borehole wall (https://www.alt.lu/). Both the amplitude and two-way travel time of its first echo from the borehole wall (geological formation) are recorded. Two-way travel-time data can be processed to calculate a $360^{\circ}$ borehole caliper. To obtain a $360^{\circ}$ image, a focusing acoustic mirror pivots around a central axis. As for the OBI images, the ABI images are oriented with respect to the magnetic north thanks to deviation sensor data and are displayed as an unfolded representation of the $360^{\circ}$ view. The image resolution is determined by the user and depends on the number of measurements made in one rotation and the rate at which the tool is raised up the borehole while measurements are made. During Expedition 364, ABI40 acoustic images from up logs were acquired with various resolutions, ranging from 288 samples by $2 \mathrm{~mm}$ to 144 samples by $4 \mathrm{~mm}$ (Table 1, Morgan et al., 2017). Acquisition of the 1st echo is automatically picked within an acoustic reflection time window whose limits can be set up either automatically or manually by the operator. The latter is useful when the formation echo is weak and can be mixed with echoes, multiples, or when borehole fluid contains particles that return a false first echo. As for the OBI, image quality will degrade with hole diameters larger than $15 \mathrm{~cm}$ and with the presence of mud in the borehole fluid due to the higher attenuation of the ultrasonic pulse. 


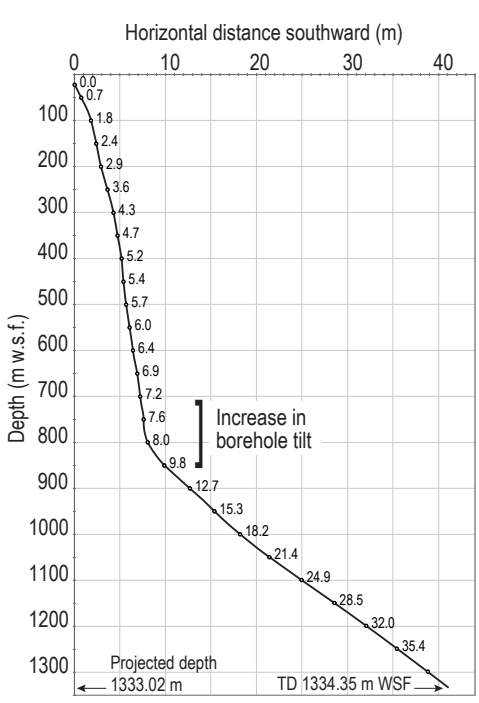

(a)

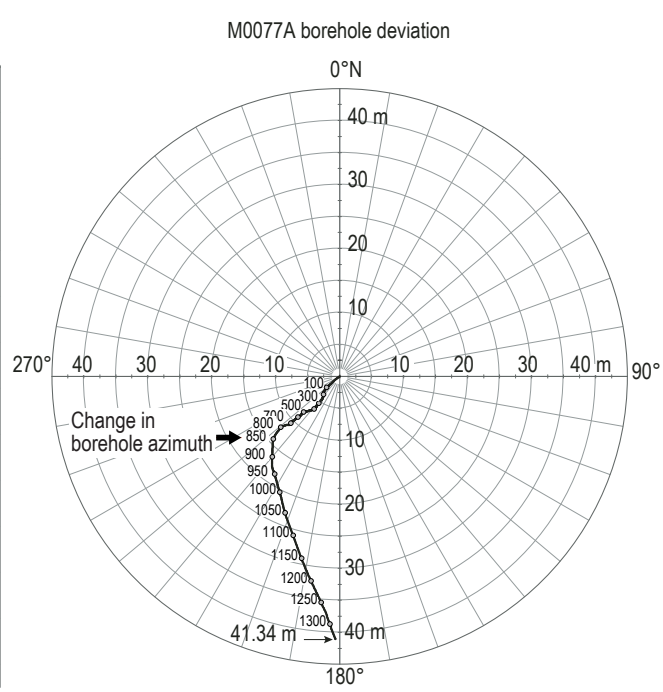

(b)

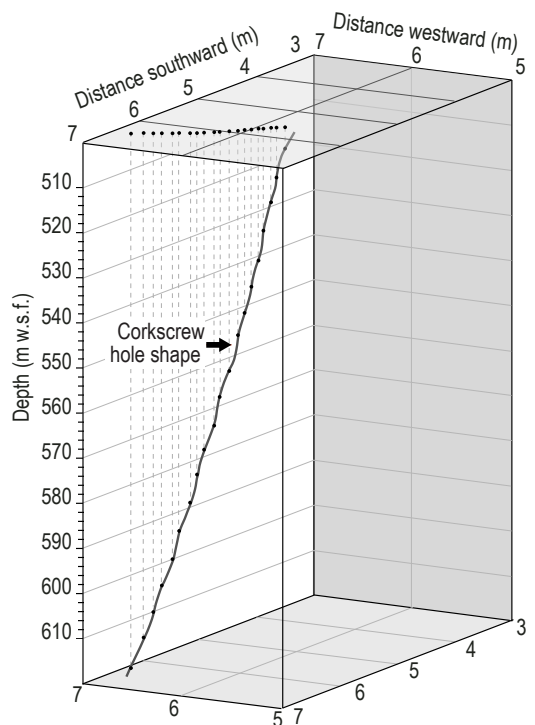

(c)

Figure 2. (a) true vertical depth and southward deviation of Hole M0077A. Note the increase in borehole tilt between 750 and $850 \mathrm{~m}$ w.s.f. (b) top view projection of the borehole path (modified from Gulick et al., 2017). Note the change in hole direction from southwest to southeast between 800 and $950 \mathrm{~m}$ w.s.f. (c) zoom on the 500-610 m w.s.f. interval in post-impact carbonates illustrating a corkscrew borehole shape. m w.s.f. is meter wireline depth below seafloor.

\section{Logging-related features}

Logging-related features arise from the downhole loggingdata acquisition phase and mainly result from logging-tool eccentering, logging-tool malfunctions, and signal perturbation by an external factor (e.g., steel pipe for magnetic data).

\subsection{Steel pipe and metal debris}

Both the OBI and ABI contain a three-axis magnetometer and three accelerometers that allow for the orientation of the logging tools with respect to the magnetic north (azimuth) and vertical direction (tilt) to be determined. Such information can be used to compute the borehole's trajectory in 3D (Fig. 2) and is key in orienting the borehole images with respect to the magnetic north. Consequently, any perturbation of the local earth's magnetic field to the borehole prevents the proper registration of the true magnetic north by the logging tool and results in incorrectly displayed or oriented borehole images. This problem is most commonly observed when, during up-log acquisition, the bottom entrance to the steel pipe or casing is approached as the presence of this ferrous metal locally distorts the magnetic field (e.g., Lofts and Bourke, 1999; Shipboard Scientific Party, 1993). During Expedition 364, this phenomenon has been clearly observed in both $\mathrm{ABI}$ and $\mathrm{OBI}$ data. In Fig. 3, perturbation in the ABI image and azimuth starts about $1.4 \mathrm{~m}$ below the casing entrance and increases upward (Fig. 3a, b, d). A deviation in the magnetic field intensity is also observed, starting $\sim 2.5 \mathrm{~m}$ below the casing (Fig. 3e). The disturbance of the total magnetic field (Fig. 3e), calculated from the three magnetometer components $(X, Y, Z)$, starts deeper than the one of the azimuth (Fig. 3d), which is derived from the radial components $(X$, $Y$ ). This is because the axial component of the pipe magnetization is stronger than the radial one. As a consequence, the axial component $(Z)$ of the magnetometers on the logging tool is more influenced by the pipe further below than the radial components $(X, Y)$ that are disturbed much closer to the pipe. Importantly, it is also notable that the depths at which the perturbations are observed below the pipe entrance are overestimated by $\sim 1.2 \mathrm{~m}$ for both the ABI image and azimuth and the total magnetic field intensity logs. This is related to the way the ABI images are processed in the WellCAD software and how the depths of the various sensors are displayed. Indeed, for a given depth, the $360^{\circ} \mathrm{ABI}$ image is oriented with respect to the magnetic north thanks to the deviation sensor data that are acquired $1.2 \mathrm{~m}$ above the acoustic window data at the same instant. The magnetic field is thus assumed to be constant over this $1.2 \mathrm{~m}$ long interval, which is true most of the time, with the exception of the presence of a strong magnetic anomaly such as the one generated by the casing. As a consequence, the perturbation of the total magnetic field starts in reality about $1.3 \mathrm{~m}$ below the casing entrance while the perturbation of the azimuth occurs when the magnetometers inside the $\mathrm{ABI}$ almost reach the casing shoe. For future works on the IODP expedition 364 downhole magnetic data from Site M0077, both the azimuth and 


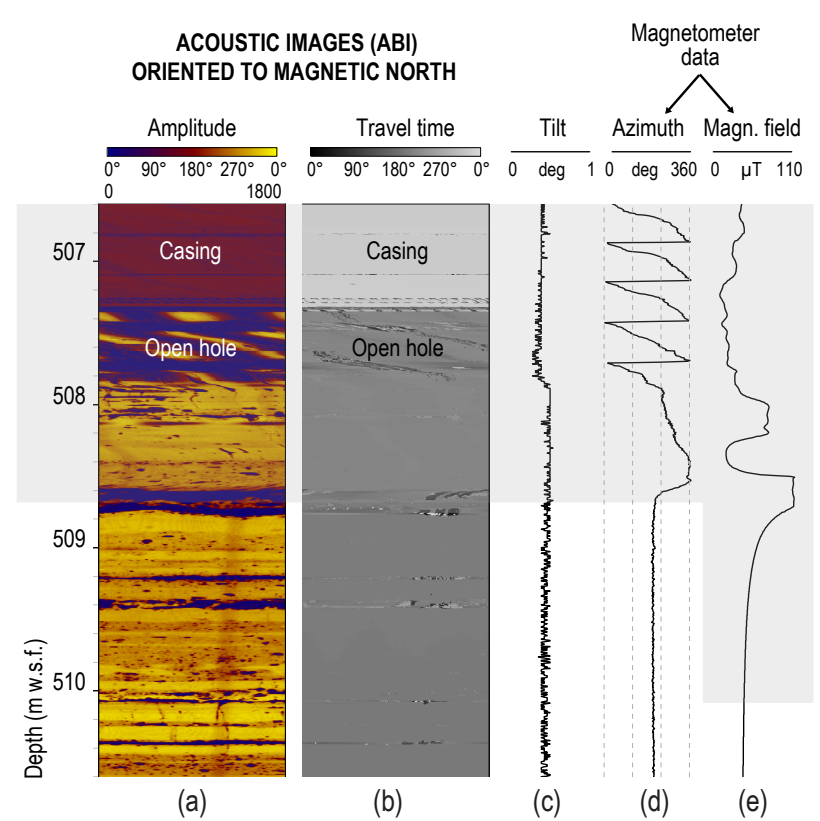

Figure 3. Commonly encountered magnetometer perturbation observed when approaching the entrance of a steel pipe or casing as the presence of metal close to the tool perturbs the magnetic field (d, e). As a result, the acoustic borehole image is incorrectly displayed and oriented $(\mathbf{a}, \mathbf{b})$. Grey shaded area indicates the zone under casing influence, overestimated here (see discussion in Sect. 3.1). m w.s.f. is meter wireline depth below seafloor.

magnetic field logs should thus be shifted upward by $1.2 \mathrm{~m}$ over the entire hole before any interpretation.

Localized perturbations in the magnetometer data have also been noted elsewhere in open hole along the borehole and may possibly be related to the presence of highly magnetized formations (Gaillot et al., 2004). The presence of pieces of metal lodged in the borehole wall as a consequence of technical difficulties during the drilling operations can also cause perturbations in the magnetometer data (e.g., azimuth and magnetic field spikes at $\sim 851 \mathrm{~m}$ w.s.f. in Fig. $4 \mathrm{~m}$ ). These metal pieces are also revealed by anomalous spikes on both the magnetic susceptibility (MSUS) and formation conductivity (IL) $\operatorname{logs}$ (e.g., $\sim 850$ m w.s.f. on Fig. 4 n). Note that the azimuth and magnetic field spikes are lying $\sim 1 \mathrm{~m}$ below the MSUS and IL spikes as a result of the $1.2 \mathrm{~m}$ processing offset previously discussed. Once corrected from this offset, all anomalies align coherently at the same depth ( $\sim 850$ m w.s.f.).

\subsection{Logging tool eccentering effect on images}

Logging tool eccentering commonly occurs in non-circular holes or over intervals that are caved or washed out beyond the dimensions of the centralizers (e.g., Lofts and Bourke, 1999). As a consequence, the logging tool is no longer centered in the borehole. Not all the wireline logging tools are sensitive to eccentering, which particularly affects acoustic borehole imaging quality.

During Expedition 364, the ABI and OBI logging tools were run with two centralizers to ensure tool centralization. Yet, tool eccentering appears to have affected the ABI data across some depth intervals. Tool eccentering is generally expressed by dark and light stripes on the amplitude images, as eccentering causes the amplitude to increase at azimuths where the tool is closer to the borehole wall, and vice versa (e.g., Lofts and Bourke, 1999). In Hole M0077A, loggingtool eccentering is illustrated in Fig. 5 by two sets of ABI data acquired over the same depth interval (Fig. 5-1 and 5-2). Travel-time cross sections clearly illustrate the non-circular shape of the hole over this interval (Fig. 5c, f). On the amplitude images two dark stripes (see blue arrows in Fig. 5a, d) appear as regular, almost vertical non-planar features that are not randomly oriented. Their azimuths are highlighted by the bold blue lines on the travel-time cross sections (Fig. 5c, f). They correlate with portions of the borehole wall that are orientated obliquely with respect to the incident angle of the acoustic wave. This sloping angle of incidence is likely to lead to signal scattering over these sections of the borehole and be associated with low amplitudes in the recorded data. The amplitude of the acoustic signal indeed depends on the surface roughness of the borehole wall, the acoustic impedance contrast between the borehole fluid (or mud cake) and the formation, the attenuation in the borehole fluid, and the angle of incidence. In this case, logging-tool eccentering is not expressed by the classical dark and light stripes at $180^{\circ}$ from each other (Lofts and Bourke, 1999), probably because the eccentering occurs in a non-circular-shaped hole (Fig. 5c and f) instead of a circular one.

Over the same interval, the azimuths of the two dark stripes are not the same when comparing Up-log 1 (Fig. 5a, c) and Up- $\log 2$ (Fig. 5d, f). This difference suggests that the position of the logging tool in the hole was different, and that the tool followed two different trajectories during the successive up-logs. The amplitude images acquired on up-logs 1 and 2 (Fig. 5a, d) have been merged (Fig. 5g). The resulting image clearly shows an abrupt jump in the orientation of the dark low amplitude stripes at $\sim 610.6 \mathrm{~m}$ w.s.f. This feature, which is entirely related to eccentering, should not be misinterpreted and taken as an incorrect display or orientation of one of the two ABI images (either Up-log 1 or Up-log 2). Indeed, the correct orientation of both Up-log 1 and Up-log 2 images is confirmed by the " $F$ " sedimentary feature which displays the same orientation on each of the amplitude and travel-time images (white arrows in Fig. 5a, b, d, e, g).

\section{Drilling-related features}

Drilling-related features are physically produced during the drilling or coring phase. They include any operation that may have affected the shape or trajectory of the hole (e.g., ream- 


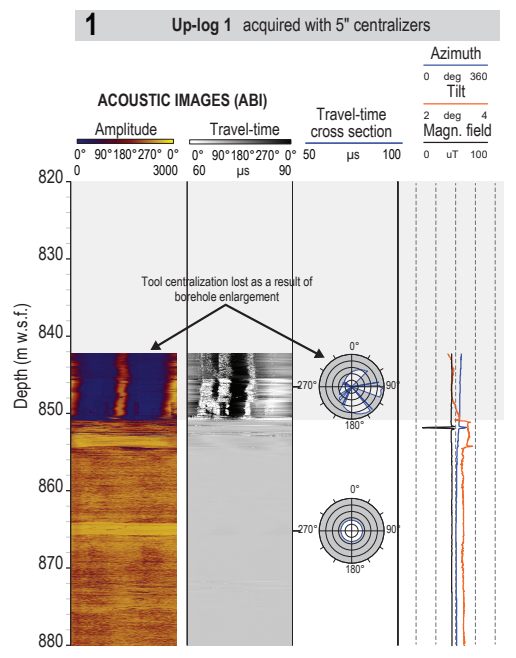

(a)

(b)

(c)

(d)

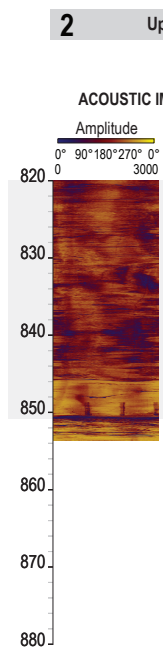

(e)
Up-log 2 acquired with $6 "$ centralizers

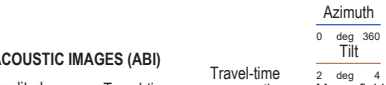

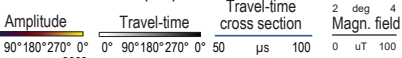

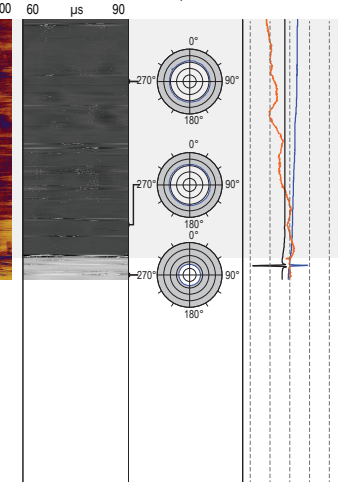

(f)

(g)

(h)

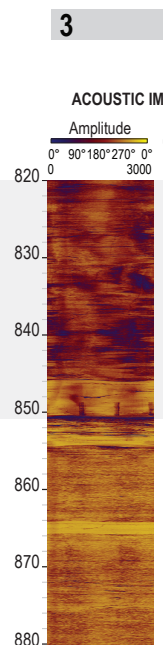

(i)
Merged up-logs 1 and 2

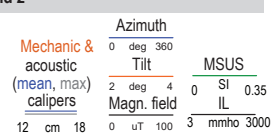

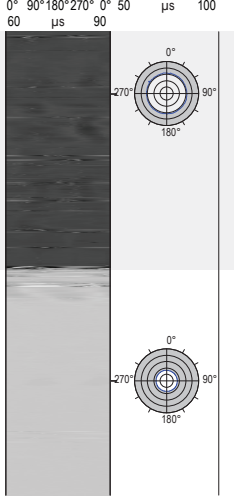

(j)

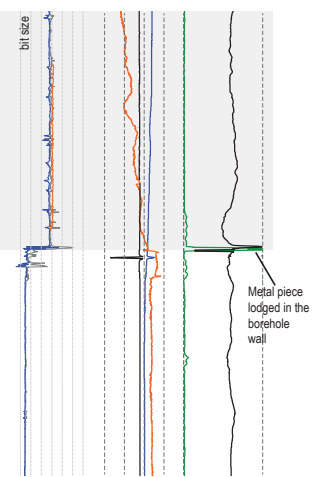

(k)

(I)

(m)

(n)

Figure 4. Drilling induced borehole enlargement as a result of fallen metal pieces (see discussion in Sect. 4.3). (1) Up-log 1; (2) Up-log 2; (3) merged Up 1 and Up 2 logs. Change in borehole diameter is evidenced at $\sim 850 \mathrm{~m}$ w.s.f. by acoustic borehole image data (b, f, j, l). The presence of steel pieces lodged in the borehole wall at the same depth is highlighted by azimuth, magnetic field, magnetic susceptibility, and conductivity spikes $(\mathbf{m}, \mathbf{n})$. Note that the travel-time cross sections' lower limits have been set to $50 \mu$ s $(\mathbf{c}, \mathbf{g}, \mathbf{k})$. $\mathrm{m}$ w.s.f. is meter wireline depth below seafloor.

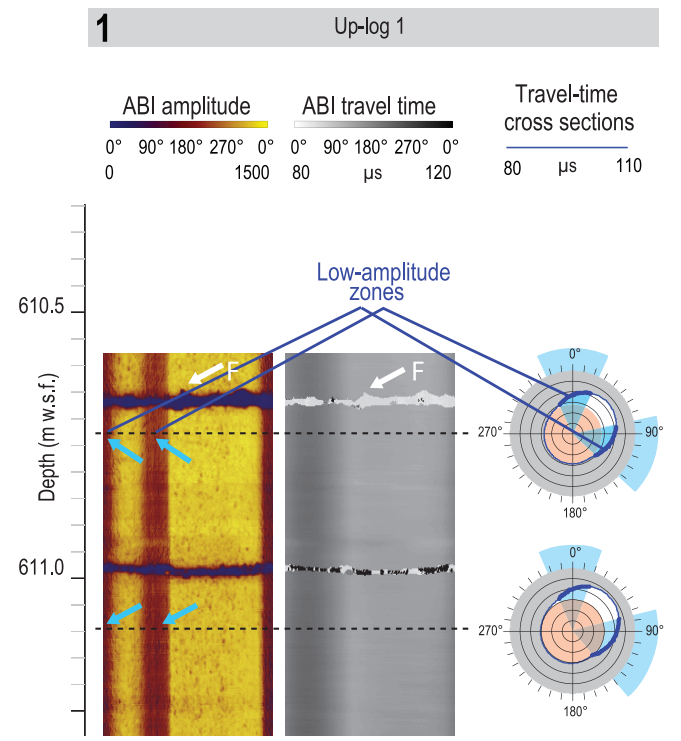

(a) (b)
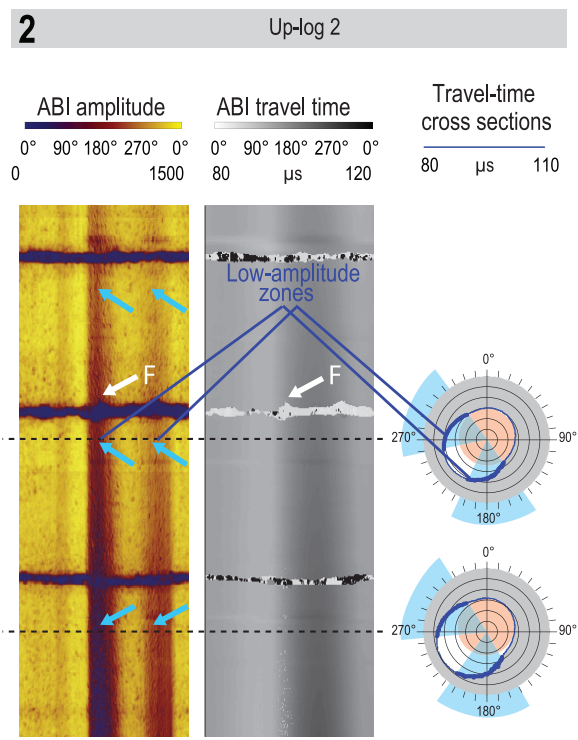

(d)

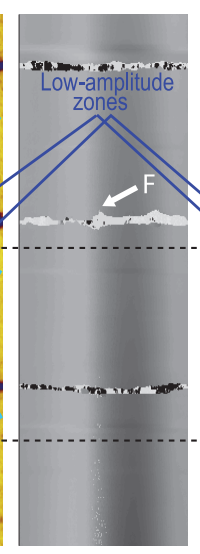

(e)

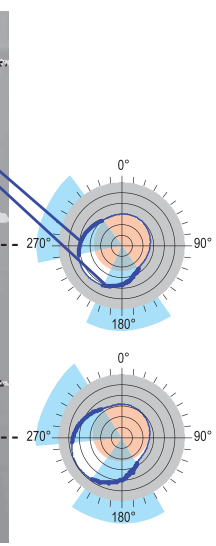

(f)
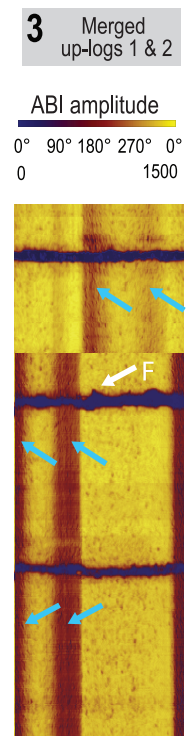

(g)

Figure 5. Example of tool eccentering effect in a non-circular borehole. (1) Up-log 1; (2) Up-log 2; (3) merged Up 1 and Up 2 logs. Two dark low-amplitude stripes (blue arrows) are observed on the ABI amplitude images (a, d). Their location is highlighted with the bold blue lines on the travel-time cross sections (c, f). Over the same interval, the azimuth of these stripes varies depending on the up-log (1 or 2), resulting in a stepped change in stripe orientation on the merged image (g). This is interpreted as a change in tool eccentering between the two successive acquisition passes. The sedimentary feature "F" (white arrows), which shows the same azimuth on both up-logs (a, d, g), attests to the correct orientation of both sets of images. Note that travel-time cross sections' lower limits have been set to $80 \mu$ s $(\mathbf{c}, \mathbf{f})$. $\mathrm{m}$ w.s.f. is meter wireline depth below seafloor. 


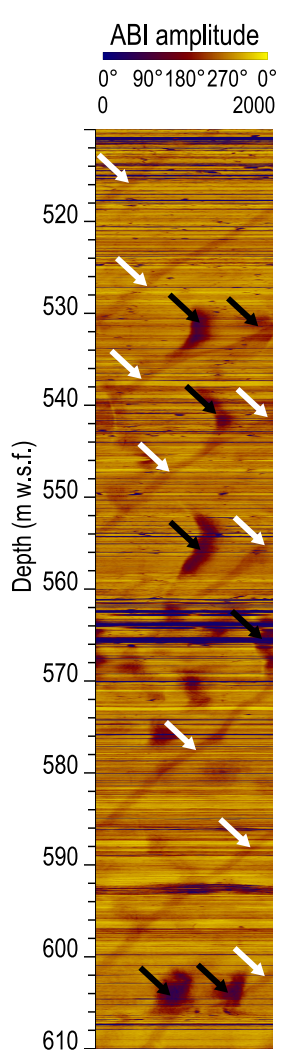

(a)
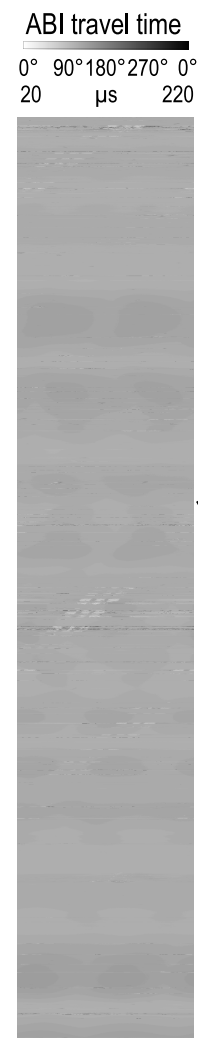

(b) (c)

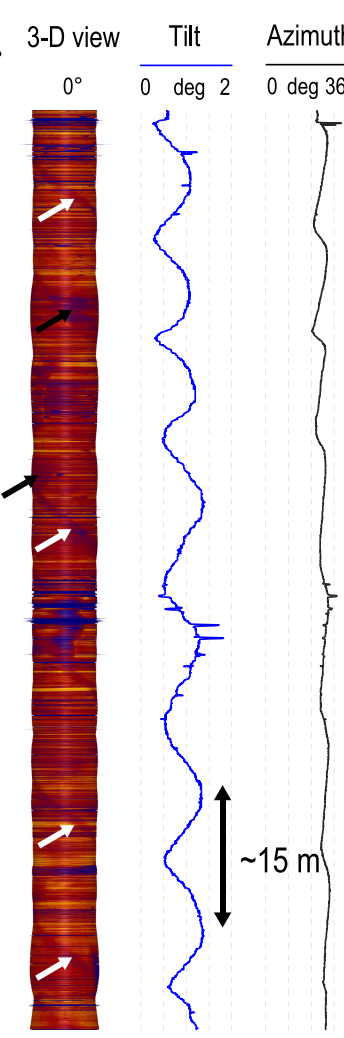

(d)

(e)

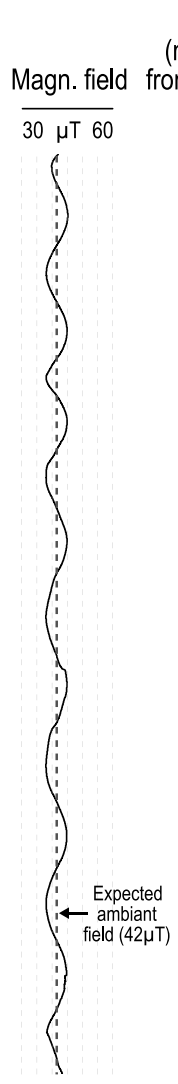

(f)
Caliper

(mean,max) Inclination NRM

$m$ travel time (core data)
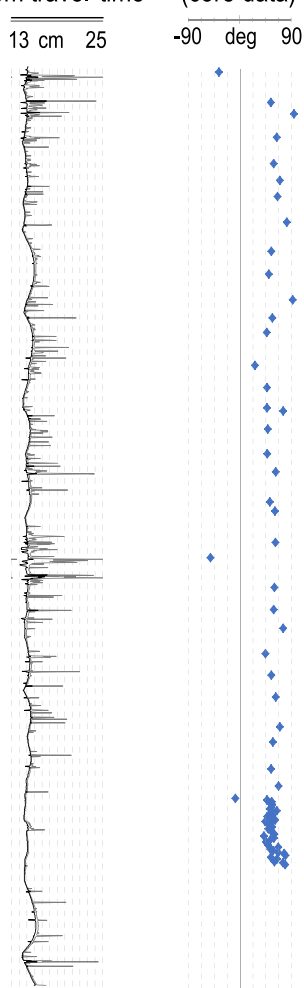

(g)

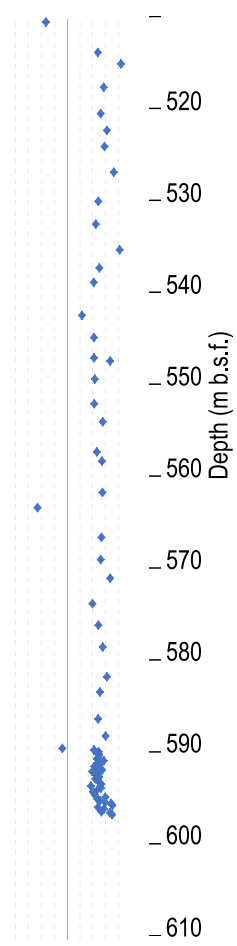

(h)

Figure 6. Drilling-induced corkscrew borehole shape in the post-impact carbonates, possibly due to drill bit wobble, steel wedged at the bit or overfeed of rods. This shape (see also Fig. 2c) is evidenced by cyclic oscillations in both accelerometer (tilt) and magnetometer (azimuth) data (d, e). One continuous regular spiraling narrow dark stripe (white arrows in a and c) may result of the drill pipe rubbing on the carbonate formation. Drilling induced re-magnetization of the formation is tentatively proposed to account for the cyclic changes observed in the magnetic field (f). (h) Non-demagnetized NRM measured on core samples dominated by positive inclination (indicative of normal polarity), suggesting a pervasive normal polarity remagnetization. $\mathrm{m}$ w.s.f. is meter wireline depth below seafloor; $\mathrm{m}$ b.s.f. is meters below seafloor.

ing), drill marks on the borehole wall, and the in situ pollution by debris produced by the drilling operations (e.g., here, metal pieces of casing and stuck drill bits that were ground up).

\subsection{Corkscrew hole and formation re-magnetization}

Boreholes are rarely drilled as perfect vertical cylinders. In particular, some drilling operations can cause the borehole to take the shape of a corkscrew (spiral). Such a shape can result from drilling and reaming operations including the bit-whirl and wiper trips. In the post-impact carbonates at Site M0077, 10 to $15 \mathrm{~m}$ long regular undulations are observed in both the tilt and azimuth of the ABI logging-tool data between 510 and $610 \mathrm{~m}$ w.s.f. (Fig. 6d, e). Tilt and azimuth are provided by two distinct types of sensors, accelerometers (accuracy: \pm 0.5 degree) and magnetometers (accuracy: \pm 1.2 degree), respectively. The observed undulations are interpreted as reflecting a corkscrew shaped hole (see zoom of the borehole trajectory over this depth interval in Fig. 2c). Oscillations $<2 \mathrm{~cm}$ in the acoustic borehole caliper are also observed with a shorter wavelength (2-8 m). The local presence of one or two large low-amplitude dark stripes on the ABI amplitude image (black arrows in Fig. 6a, c) occurred where the borehole shows a non-circular shape and is enlarged. As discussed in Sect. 3.2, these stripes possibly reflect logging-tool eccentering. Superimposed on these possible eccentering features, the amplitude image also displays one continuous, spiraling, narrow dark stripe (white arrows in Fig. 6a, c) wherein the path is independent of the changes in borehole diameter and shape in cross section. A clear link is, however, observed between the orientation of this stripe and the tilt and azimuth (Fig. 6a, $\mathrm{d}, \mathrm{e})$. The origin of the stripe remains unclear, but based on the tight link with borehole geometry, we suggest that it may reflect a mark on the borehole wall (see also Sect. 4.2) resulting from the drill pipe rubbing the carbonate formation 
during operations. This can occur as the bit engages the formation and the stand drill-pipe torques into a helical.

At the drill site, the expected ambient field intensity as given by the World Data Center for Geomagnetism (http: //wdc.kugi.kyoto-u.ac.jp/index.html, last access: 12 October 2018) is $\sim 42 \mu \mathrm{T}$ (Fig. 6f), which corresponds to the mean intensity value measured by the magnetometers over the 510 and $610 \mathrm{mw}$ w.s.f. intervals. However, apparent 10$15 \mathrm{~m}$ long cyclic oscillations in the local magnetic field are also observed with values ranging between 38.2 and $45.5 \mu \mathrm{T}$ (Fig. 6f). These oscillations in the magnetic field intensity (as measured by the magnetometers) vary jointly with the borehole tilt (as measured by the accelerometers). High values in the local magnetic field (Fig. 6f) correlate with high tilts (Fig.6d), and vice versa. We tentatively interpreted this cyclical pattern in magnetic field intensity as a possible drillinginduced magnetization overprint in the surrounding rocks. Indeed, in the 510 and $610 \mathrm{~m}$ w.s.f. interval, the lithology mainly consists of marlstone and limestone (Morgan et al., 2017) with low coercivity (Urrutia-Fucugauchi et al., 2017). Such material is susceptible to acquiring drilling-induced magnetization (e.g., Jackson and Van der Voo, 1985). The effect of drilling and sawing on the magnetization of rocks is a known phenomenon, and the magnetic overprint imparted by the drill string is a problem commonly encountered in cores taken by the IODP (e.g., Fuller et al., 1998). Preliminary paleomagnetic measurements performed on discrete samples within this depth interval (Fig. 6h) suggest that a pervasive normal polarity re-magnetization of the carbonates likely occurred within the low-coercivity fraction of magnetic grains, supporting the idea that overprinting may readily occur in this formation. Therefore, we suggest that the drilled carbonates have undergone magnetization overprinting during the drilling operations possibly as a result of the rotary perforation of the formation associated with the presence of a steel BHA, steel wedged at the bit or overfeed of rods. As the changes in ambient field intensity follow the changes in the borehole tilt, we also suggest a possible link between the degree of drilling-induced magnetization and the drilling conditions that cause the borehole to take the shape of a corkscrew.

\subsection{Borehole wall drilling marks}

During Expedition 364, helical stripes with a wavelength of $\sim 0.2 \mathrm{~m}$ are observed locally on the borehole wall images acquired in the peak-ring granitoids (Fig. 7). They are evidenced through either low amplitudes zones on the ABI images or dark zones the OBI images (arrows in Fig. 7a, b, d). They are also slightly visible on the travel-time images (Fig. 7a). Unlike the corkscrew related stripes (see Sect. 4.1 above), these stripes are not associated with any changes in the borehole tilt or azimuth (Fig. 7e, f). They are interpreted as drilling-induced markings on the borehole wall, left by a drilling tool in a relatively soft, shock-metamorphosed gran- ite with an unusually low density (Morgan et al., 2016, 2017; Christeson et al., 2018).

In another example, at a larger scale, a low amplitude, dark stripe (Fig. 8d) is observed in the lower half of the hole (Fig. 8d) where the tilt is increased to about $4.2^{\circ}$ (Fig. $2 \mathrm{a}$ and b). The mean orientation of the path of the stripe is $\sim 25^{\circ} \mathrm{N}$ (Fig. 8d). Orienting the image to the high side (Fig. 8g) instead of to the magnetic north (Fig. 8d) clearly shows that the stripe is parallel to the axis of the hole, thus illustrating a clear link between the presence of this stripe and the borehole inclination. We thus tentatively interpreted this largescale stripe as a key-seat-related feature that developed in the inclined part of the hole because the drill pipe was rubbing the bottom side of the borehole. However, no clear groove cut is observed on the acoustic caliper data (Fig. 8f). In addition, the stripe is not oriented to $180^{\circ}$ (i.e., aligned on the lowest part of the hole), as expected from a key seat, but at $\sim 220^{\circ}$, i.e., with an offset of $\sim 40^{\circ}$ (Fig. $8 \mathrm{~g}$ ) westward. This angular offset may result from the change in azimuth of the hole observed at $850 \mathrm{~m}$ w.s.f. (Fig. 2b), which deviated the drill pipe and forced it to the lateral westward side of the borehole.

\subsection{Drilling induced borehole enlargement}

Below $~ 700$ mw.s.f., the borehole shape at Site M0077 was good to excellent (Fig. 1e). During up-log ABI data acquisition, logging-tool centralization was however lost at $\sim 850 \mathrm{~m}$ w.s.f. (Fig. 1d), suggesting drastic borehole enlargement. The tool string was brought back to the surface and the $5^{\prime \prime}$ centralizers replaced by $6^{\prime \prime}$ centralizers. These later allowed for a proper centralization of the logging tool string from 850 to $\sim 702 \mathrm{~m}$ w.s.f. (casing entrance). As shown in Fig. 41, this borehole enlargement is confirmed by acoustic travel-time data that evidence a change in diameter from $\sim 12.5 \mathrm{~cm}$ (close to the outside diameter of the drill bit of $12.26 \mathrm{~cm})$ below $850 \mathrm{~m}$ w.s.f. to $\sim 14.7 \mathrm{~cm}(\sim 2.5 \mathrm{~cm}$ larger than the outer bit diameter) above $850 \mathrm{~m}$ w.s.f. (Fig. 1a). The enlarged borehole diameter is observed over the entire 850702 m w.s.f. interval (Fig. 1e).

No clear explanation exists to account for this oversized borehole since (1) although the drill bit has been replaced by a new one at $823.24,829.34$ and 851.65 DSF (driller's depth below seafloor), the entire $702-1334 \mathrm{~m}$ b.s.f. interval was nominally drilled with the same bit size (Fig. 1a), and (2) no major change in lithology is observed at $850 \mathrm{~m}$ w.s.f., except for the presence of a $\sim 5 \mathrm{~m}$ thick dolerite dike intrusion, extending from 846.3 to $851.1 \mathrm{~m}$ b.s.f. (Fig. 1c). This dike is characterized by a high amplitude on the ABI image (yellowish color in Fig. 4e, i), as dolerites are harder than the surrounding granite. It also has a higher magnetic susceptibility (Fig. 4n), as dolerites are enriched in iron compared to granitoids. The change in lithological properties when entering in the dolerite dike was probably responsible for the need to change the drill bit at $~ 851$ DSF. However, it cannot 


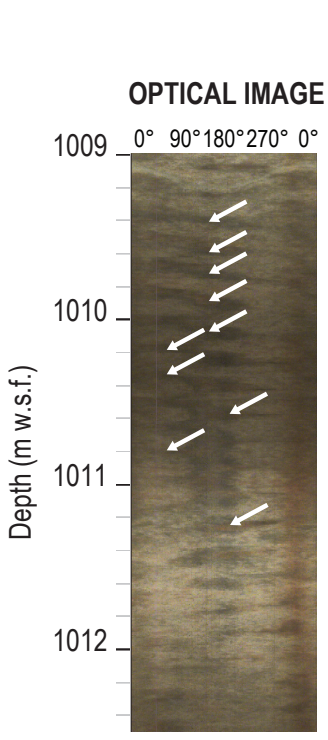

(a)
ACOUSTIC IMAGES (ABI)

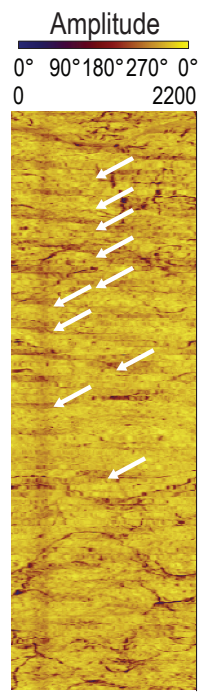

(b)

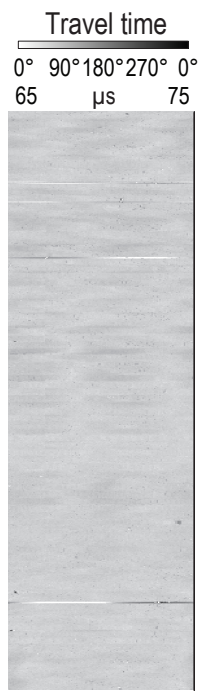

(c)

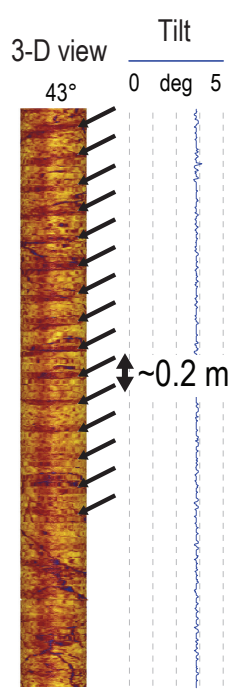

(d)

(e)

\section{Caliper \\ (mean,max) \\ from travel time \\ $\overline{12 \mathrm{~cm} 14}$}

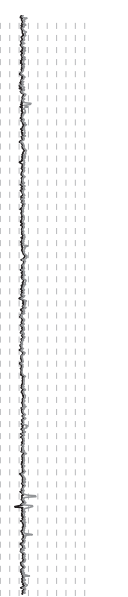

(h)

Figure 7. Drilling-induced helical marking on the borehole wall, evidenced by helical stripes (arrows) on both the optical and acoustic borehole images. $\mathrm{m}$ w.s.f. is meter wireline depth below seafloor.

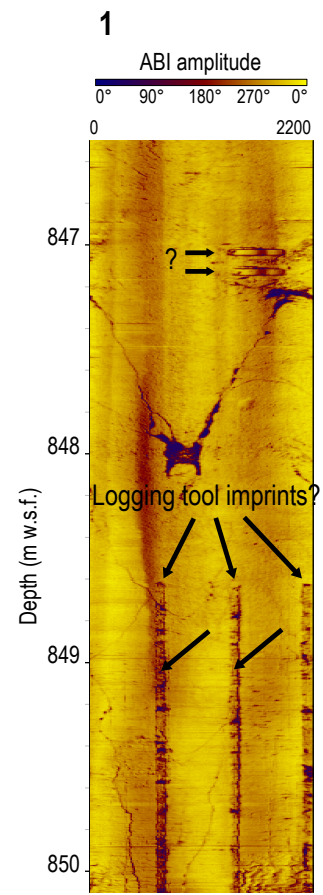

(a)

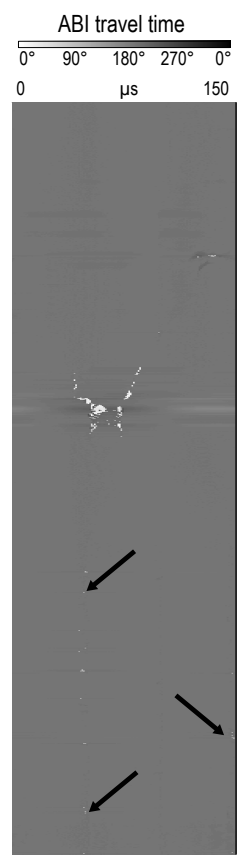

(b)

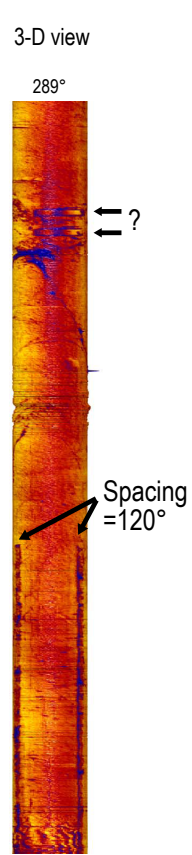

(c)

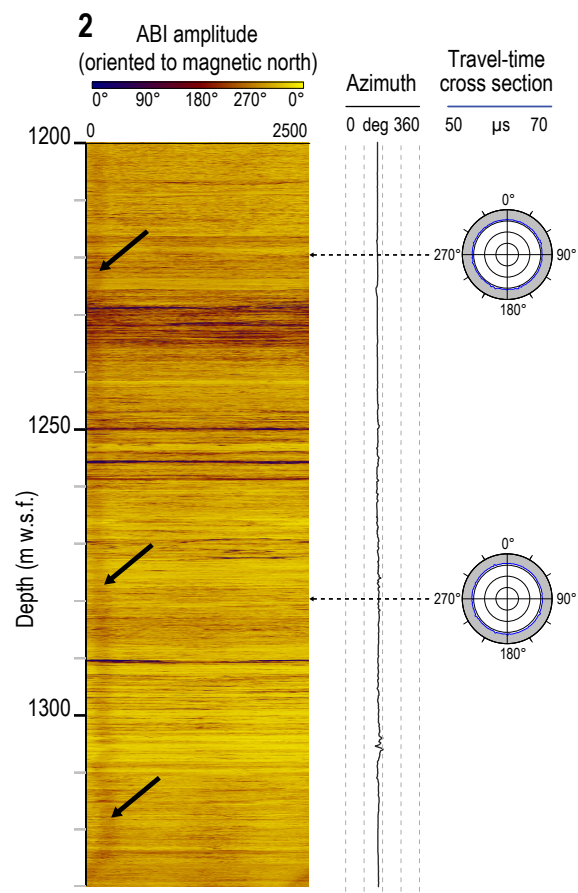

(d) (e)

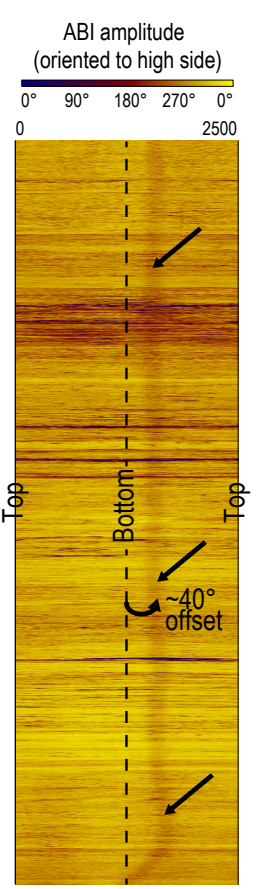

(g)

Figure 8. Marks on the borehole wall. (1) possible tool imprint oriented to $120^{\circ}$, and residue possibly left in mud residue by arms of the mechanical caliper. (2) ABI image oriented with respect to the magnetic north (d) and to the high side, (g) illustrating that the continuous regular narrow dark stripe (black arrows) is closely related to borehole inclination and may be the result of the drill pipe rubbing on the borehole wall. (f) travel-time cross section (magnetic north orientation) illustrates a regular borehole shape with no evidence for groove cut to be associated with the narrow dark stripe. Note that the travel-time cross sections' lower limit has been set to $50 \mu$ s. 
explain why the borehole diameter is oversized above that depth.

Besides the change in borehole diameter, large spikes in both conductivity and magnetic susceptibility are also noticeable at $\sim 850 \mathrm{~m}$ w.s.f. (Fig. $4 \mathrm{n}$ ). These anomalies are not observed on resistivity and magnetic susceptibility MSCL data acquired on whole round cores taken at the same depth (Morgan et al., 2017), and we consequently interpret these spikes as reflecting the presence of pieces of metal lodged in the borehole wall. This interpretation appears to be confirmed by pieces of steel that were found in the liners of cores 136R-138R (850.6-852.9 m DSF), among which a large piece $(>1 \mathrm{~cm})$ of a casing shoe found in the liner of core 137R (Fig. 1a) and coming from the casing shoe positioned at $\sim 702 \mathrm{~m}$ w.s.f. Some other pieces possibly come from a misaligned casing located at $\sim 307 \mathrm{~m}$ w.s.f., which we drilled through during the coring operations, as well as from a broken drill bit (Fig. 1a, picture of drill bit replaced at $701.6 \mathrm{~m} \mathrm{DSF}$ ). In order to explain for the oversized borehole diameter over the $702-850 \mathrm{~m}$ w.s.f. interval, we tentatively suggest that some large pieces of casing shoe and damaged drill bit were trapped outside the drill bit during the coring phase, which led to an enlargement of the hole over this entire interval in the relatively soft granitic basement. The damages done to the successive drill bits are illustrated in Fig. 1a (pictures of drill bits replaced at 823.2 and $829.3 \mathrm{mDSF}$ ). Although the hole shape remained relatively subcircular, a change in borehole quality is clearly observed on both the ABI amplitude image (Fig. 4i) and mean caliper (Fig. 4l) when crossing $850 \mathrm{~m}$ w.s.f., with a smoother borehole below $850 \mathrm{~m}$ w.s.f. and a more rugose one just above. The presence of these pieces of metal outside the drill bit also seems to have affected the borehole trajectory at some point, since a drastic increase of the borehole tilt and a clear change in the borehole azimuth are observed from $\sim 750$ to $850 \mathrm{~m}$ w.s.f. (Fig. 1f and Fig. 2a, b). The above observations are a nice example of how operational difficulties at shallower depths indirectly induced changes in borehole diameter, shape and trajectory at greater depths.

Just before the change in borehole diameter described above, we noticed the presence in both the amplitude and travel time of borehole images of an unusual feature consisting of three vertical narrow stripes oriented to $120^{\circ}$ and extending from 846 to $850.4 \mathrm{~m}$ w.s.f. (Fig. $8 \mathrm{a}$, b). This feature cannot be interpreted as drill marks (see also Sect. 4.2) on the borehole wall, since no drill tool with such a shape has been used during the drilling/coring operations. We believe that these marks have been left by the three arms of the mechanical caliper in a thin layer of mud residue covering the borehole wall. This mud may have been left over from the formation during flushing because of the borehole enlargement and associated increase in the annular space between the pipe and the geological formation, thus reducing annular circulating fluid velocity. If this interpretation is correct, this is an example of a combined drilling- and logging-induced feature. Above these vertical imprints, two sub-horizontal features are observed at $\sim 847 \mathrm{~m}$ w.s.f. (Fig. $8 \mathrm{a}$ ). Their origin remains unknown so far.

\section{Conclusions}

Differentiating geological features from operation-related features is critical for downhole logging-data quality control and interpretations. High quality data were acquired downhole with slimline tools during the IODP-ICDP Expedition 364. Yet, some non-geological features are observed and illustrated in this paper. Such features are grouped in two families: logging-related and drilling-induced features. We mainly focus on acoustic borehole images that provide invaluable source of information for sub-surface geology characterization but are also very sensitive to acquisition context and borehole conditions. Slimline tools are often used in MSP expeditions (e.g., IODP Expeditions 310, $313,325,364,381$ ), as MSPs employ various coring technologies and pipe sizes that provide constraints on the diameters of logging tools to be used. This methodology is different from other IODP platforms, the JOIDES Resolution and the Chikyu, where the fixed larger pipe sizes allow larger diameter standard sets of logging tools to be deployed. The logging-related and drilling-induced features presented and discussed in this paper are based on data acquired with slimline tools, but most of them should be valid for standard tools.

Data availability. Downhole logging data are stored and made available on the IODP log database (see also page 3 , second paragraph in this article): http://mlp.ldeo.columbia.edu/logdb/ scientific_ocean_drilling/

Team list. Expedition 364 Scientists: Sean P. S. Gulick (Institute for Geophysics and Department of Geological Sciences, Jackson School of Geosciences, University of Texas at Austin, Austin, TX, USA), Joanna V. Morgan (Department of Earth Science and Engineering, Imperial College London, London, UK), Elise Chenot (Biogéosciences Laboratory, Université de Bourgogne-Franche Comté, Dijon, France), Gail L. Christeson (Institute for Geophysics and Department of Geological Sciences, Jackson School of Geosciences, University of Texas at Austin, Austin, TX, USA), Philippe Claeys (Analytical, Environmental and Geo-Chemistry, Vrije Universiteit Brussel, Brussels, Belgium), Charles S. Cockell (Centre for Astrobiology, School of Physics and Astronomy, University of Edinburgh, Edinburgh, UK), Marco J. L. Coolen (Department of Chemistry, WA-Organic and Isotope Geochemistry Centre, Curtin University, Perth, Western Australia, Australia), Ludovic Ferrière (Natural History Museum, Vienna, Austria), Catalina Gebhardt (Alfred Wegener Institute Helmholtz Centre of Polar and Marine Research, Bremerhaven, Germany), Kazuhisa Goto (International Research Institute of Disaster Science, Tohoku University, Sendai, Japan), Sophie Green (British Geological Survey, Edinburgh, UK), 
Heather Jones (Department of Geosciences, Pennsylvania State University, University Park, PA, USA), David A. Kring (Lunar and Planetary Institute, Houston, TX, USA), Chris M. Lowery (Institute for Geophysics and Department of Geological Sciences, Jackson School of Geosciences, University of Texas at Austin, Austin, TX, USA), Claire Mellett (British Geological Survey, Edinburgh, UK), Rubén Ocampo-Torres (ICPEES, Université de Strasbourg, Strasbourg, France), Ligia Perez-Cruz (Instituto de Geofísica, Universidad Nacional Autónoma De México, Mexico City, Mexico), Annemarie E. Pickersgill (School of Geographical and Earth Sciences, University of Glasgow, Glasgow, UK), Michael Poelchau (Department of Geology, University of Freiburg, Freiberg, Germany), Auriol S. P. Rae (Department of Earth Science and Engineering, Imperial College London, London, UK), Cornelia Rasmussen (Institute for Geophysics and Department of Geological Sciences, Jackson School of Geosciences, University of Texas at Austin, Austin, TX, USA), Mario Rebolledo-Vieyra (Independent consultant, Cancun, Mexico), Ulrich Riller (Institut für Geologie, Universität Hamburg, Hamburg, Germany), Honami Sato (Japan Agency for Marine-Earth Science and Technology, Kanagawa, Japan), Jan Smit (Faculty of Earth and Life Sciences (FALW), Vrije Universiteit Amsterdam, Amsterdam, Netherlands), Naotaka Tomioka (Kochi Institute for Core Sample Research, Japan Agency for Marine-Earth Science and Technology, Kochi, Japan), Jaimie Urrutia-Fucugauchi (Instituto de Geofísica, Universidad Nacional Autónoma De México, Mexico City, Mexico), Michael T. Whalen (Department of Geosciences, University of Alaska Fairbanks, Fairbanks, AK, USA), Axel Wittmann (LeRoy Eyring Center for Solid State Science, Arizona State University, Tempe, AZ, USA), Long Xiao (School of Earth Sciences, Planetary Science Institute, China University of Geosciences, Wuhan, China), Kosei E. Yamaguchi (Department of Chemistry, Toho University, Chiba, Japan), and third party scientists Tim J. Bralower (Department of Geosciences, Pennsylvania State University, University Park, PA, USA).

Author contributions. PAP and BC helped in interpreting the downhole data. All other coauthors participated in sampling and data collection offshore and/or onshore during IODP-ICDP Expedition 364. All authors contributed to the writing and editing of the manuscript.

Competing interests. The authors declare that they have no conflict of interest.

Acknowledgements. Expedition 364 was funded by IODP with co-funding from ICDP and implemented by ECORD, with contributions and logistical support from the Yucatán state government and the National Autonomous University of Mexico. Drilling Services were provided by DOSECC Exploration Services. The drillers are acknowledged for their hard work and the captain and crew of the $L / B$ Myrtle are thanked for having made our life easier during the offshore phase of this expedition. We also wish to warmly thank the wide ECORD Science Operator (ESO) team for its precious contribution, especially the offshore team, including the drilling coordinators. Jochem Kück and an anonymous reviewer are thanked for their very constructive comments in reviewing the manuscript.
Edited by: Tomoaki Morishita

Reviewed by: Jochem Kück and one anonymous referee

\section{References}

Anderson, R. N. and Zoback, M. D.: The implications of fracture and void distribution from bore-hole televiewer imagery for the seismic velocity of the upper oceanic crust at Deep Sea Drilling Project Holes 501 and 504B (Costa Rica Rift), Init. Rep. DSDP, 69, 255-270, 1983.

Cheung, P. S.: Microresistivity and ultrasonic imagers: tool operations and processing principles with reference to commonly encountered image artefacts, in: Borehole Imaging: applications and case histories, edited by: Lovell, M. A., Williamson, G., and Harvey, P. K., Geol. Soc. Lond., Special Publications, 159, 1, 45-57, 1999.

Christeson, G. L., Gulick S. P., Morgan, J. V., Gebhardt, C., Kring, D. A., Le Ber, E., Lofi, J., Nixon, C., Poelchau, M., Rae, A. S. P., Rebolledo-Vieyra, M., Riller, U., Schmitt, D. R., Wittmann, A., Bralower, T. J., Chenot, E., Claeys, P., Cockell, C. S., Coolen, M. J. L., Ferrière, L., Green, S., Goto, K., Jones, H., Lowery, C. M., Mellett, C., Ocampo-Torres, R., Perez-Cruz, L., Pickersgill, A. E., Rasmussen, C., Sato, H., Smit, J., Tikoo- Schantz, S. M., Tomioka, N., Urrutia-Fucugauchi, J., Whalen, M. T., Xiao, L., Yamaguchi, K. E., and Zylberman, W.: Extraordinary Rocks from the Peak Ring of the Chicxulub Impact Crater: Physical Property Measurements from IODP/ICDP Expedition 364, EPSL, 495, 1-11, 2018.

Fuller, M., Hastedt, M., and Herr, B.: Coring-induced magnetization of recovered sediment, Proc. ODP, Sci. Res., 145, 455-468, 1998.

Ekstrom, M. E., Dahan, C., Chen, M.-Y., Lloyd, P., and Rossi, D. J.: Formation imaging with microelectrical scanning arrays, The Log Analyst, 28, 294-306, 1987.

Gaillot, P., Einaudi, F., Stoll, J., and Leven, M.: General-purpose inclinometry modules in highly magnetized formations: are borehole wall microresistivity images properly oriented?, Proc. ODP, Sci. Res., 197, 1-22, 2004.

Gaillot, P., Brewer, T., Pezard, P., and Yeh, E.-C.: Contribution of Borehole Digital Imagery in Core-Log-Seismic Integration, Sci. Dril., 5, 50-53, https://doi.org/10.2204/iodp.sd.5.07.2007, 2007.

Grieve, R. and Therriault, A.: Vredefort, Sudbury, Chicxulub: three of a Kind?, Annu. Rev. Earth Plan. Sci., 28, 305-338, 2000.

Gulick, S., Morgan, J., Mellett, C. L., and the Expedition 364 Scientists: Expedition 364 Preliminary Report: Chicxulub: Drilling the K-Pg Impact Crater, IODP, 2017.

Hayman, A. J., Parent, P., Cheung, P., and Verges, P.: Improved Borehole Imaging by Ultrasonics, SPE Production and facilities, 13, 5-13, 1998.

Inwood, J., Brewer, T. S., Braaksma, H., and Pezard, P.: Integration of core, logging and drilling data in modern reefal carbonates to improve core location and recovery estimates (IODP Expedition 310), J. Geol. Soc. Lond., 165, 585-596, 2008.

Jackson, M. and Van der Voo, R: Drilling-induced remanence in carbonate rocks: occurrence, stability and grain-size dependence, Geoph. J. Intern., 81, 75-87, 1985.

Kring, D. A.: The Chicxulub impact event and its environmental consequences at the Cretaceous - Tertiary boundary, Palaeogeogr. Palaeoclimatol. Palaeoecol., 255, 4-21, 2007. 
Lofts, J. C. and Bourke, L. T.: The recognition of artefacts from acoustic and resistivity borehole imaging devices, in: Borehole Imaging: applications and case histories, edited by: Lovell, $\mathrm{M}$. A., Williamson, G., and Harvey, P. K., Geol. Soc. Lond., Special Publications, 159, 59-76, 1999.

Lovell, M., Harvey, P. K., Brewer, T. S., Williams, T., Jackson, P. D., and Williamson, G.: Application of FMS images in the Ocean Drilling Program: an overview, in: Geological Evolution of Ocean Basins: Results from the Ocean Drilling Program, edited by: Cramp, A., MacLeod, C. J., Lee, S. V., and Jones, E. J. W., Geol. Soc. Spec. Publ. London, 131, 287-303, 1998.

Morgan, J. V., Gulick, S. P. S., Bralower, T., Chenot, E., Christeson, G. L., Claeys, P., Cockell, C. S., Collins, G. S., Coolen, M., Ferrière, L., Gebhardt, C., Goto, K., Jones, H., Kring, D. A., Le Ber, E., Lofi, J., Long, X., Lowery, C., Mellet, C., Ocampo-Torres, R., Osinski, G. R., Perez-Cruz, L., Pickersgill, A., Pölchau, M., Rae, A., Rasmussen, C., RebolledoVieyra, M., Riller, U., Sato, H., Schmitt, D., Smit, J., TikooSchantz, S., Tomioka, N., Urrutia-Fucugauchi, J., Whalen, M. T., Wittmann, A., Yamaguchi, K., and Zylberman, W.: The formation of peak rings in large impact craters, Science, 354, 878-882, https://doi.org/10.1126/science.aah6561, 2016.

Morgan, J. V., Gulick, S. P. S., Mellet, C. L., Green, S. L., and the Expedition 364 Scientists: Chicxulub: Drilling the K-Pg Impact Crater, Proceedings of the International Ocean Discovery Program, 364: College Station, TX (International Ocean Discovery Program), https://doi.org/10.14379/iodp.proc.364.103.2017, 2017.

Paillet, F. L., Barton, C., Luthi, S., Rambow, F., and Zemanek, J. R.: Borehole imaging and its application in well logging - an overview, in: Borehole Imaging, edited by: Paillet, F. L., Barton, C., Luthi, S., Rambow, F., and Zemanek, J. R., Houston, Texas, (Society of Professional Well Log Analysts), 3-23, 1990.

Pezard, P. A., Lovell, M. A., and Ocean Drilling Program Leg 126 Shipboard Scientific Party: Downhole images - electrical scanning reveals the nature of subsurface oceanic crust, Eos, 71, 710, 1990.
Pezard, P. A., Hiscott, R. N., Lovell, M. A., Collela, A., and Malinverno, A.: Evolution of the Izu-Bonin intraoceanic forearc basin, western Pacific, from cores and FMS images, Geol. Soc. Lond., Special Publications, 65, 43-69, 1992a.

Pezard, P. A., Lovell, M. A., and Hiscott, R. N.: Downhole electrical images in volcaniclastic sequences of the Izu-Bonin forearc basin, western Pacific, in: Proc. ODP, Sci. Results, 126, 603-624, 1992b.

Schulte, P., Alegret, L., Arenillas, I., Arz, J. A., Barton, P. J., Bown, P. R., Bralower, T. J., Christeson, G. L., Claeys, P., Cockell, C. S., Collins, G. S., Deutsch, A., Goldin, T. J., Goto, K., GrajalesNishimura, J. M., Grieve, R. A. F., Gulick, S. P. S., Johnson, K. R., Kiessling, W., Koeberl, C., Kring, D. A., MacLeod, K. G., Matsui, T., Melosh, J., Montanari, A., Morgan, J. V., Neal, C. R., Nichols, D. J., Norris, R. D., Pierazzo, E., Ravizza, G., Rebolledo-Vieyra, M., Reimold, W. U., Robin, E., Salge, T., Speijer, R. P., Sweet, A. R., Urrutia-Fucugauchi, J., Vajda, V., Whalen, M. T., and Willumsen, P. S.: The Chicxulub asteroid impact and mass extinction at the Cretaceous-Paleogene boundary, Science, 327, 1214-1218, 2010.

Shipboard Scientific Party: Site 894, Proc. ODP, Init. Repts., 147, 45-108, https://doi.org/10.2973/odp.proc.ir.147.103.1993, 1993.

Urrutia-Fucugauchi, J., Pérez-Cruz, L., Rebolledo-Vieyra, M., Tikoo, S. M., Zylberman, W., and IODP-ICDP Expedition 364 Science Party: Rock Magnetic Properties of IODP/ICDP Expedition 364 Site M0077 Core, Chicxulub Crater - Preliminary Results, Lunar and Planetary Science XLVIII, 2017.

Zemanek, J., Caldwell, R. L., Glenn, E. E., Halcomb, S. V., Norton, L. J., and Strauss, A. J. D.: The borehole televiewer: A new logging concept for fracture location and other types of borehole inspection, J. Petr. Techn., 21, 762-774, 1969.

Zemanek, J., Glenn, E. E., Norton, L. J., and Caldwell, R. L.: Formation evaluation by inspection with the borehole televiewer, Geophysics, 35, 254-269, 1970.

Zoback, M. D. and Anderson, R. N.: Ultrasonic borehole televiewer investigation of oceanic crustal layer 2a, Costa Rica rift, Nature, 295, 375-379, 1982. 